\title{
A FENNTARTHATÓ FEJLŐdÉS, A FENNTARTHATÓSÁG ÉRTELMEZÉSI KÉRDÉSEI A MEGVALÓSÍTÁS ÉRDEKÉBEN
}

\author{
Simonyi Péter - Zsótér Brigitta
}

\begin{abstract}
Absztrakt: A fenntartható fejlődés, fenntarthatóság kifejezések Magyarországon is közismertek és széleskörüen használják azokat. Az ENSZ által 1987-ben megfogalmazott fenntartható fejlődés eredeti jelentése számos esetben átíródott napjainkra. A cikk célja nem csak az, hogy rövid történeti betekintést nyújtson a fenntarthatóság történelmi előzményeibe, felvillantsa egyes kutatók nézeteit, hanem segítsége tisztázni az ENSZ definíció esszenciáját. Továbbá kísérletet tesz a fenntarthatóság kritériumainak felállítására. Ezek segítségével folyamatok, tevékenységek értékelhetők abból a célból, hogy melyik felel meg ténylegesen a valódi fenntarthatóságnak. Az egyértelmü, hogy paradigmaváltás szükséges, azonban a fenntartható fejlődés gyakorlatba ültetése során új súlyos kérdések jelennek meg.
\end{abstract}

\begin{abstract}
Sustainable development (SD), sustainability is well known and commonly used expressions in Hungary, too. Original meaning of SD, defined by UN in 1987, has been overwritten in many cases today. The aim of this paper is not only to give a short description of history of sustainability, to give concise outline of some researchers' opinion on sustainability but by help of them to clarify the essence of the UN definition. There is an attempt to establish criteria of sustainability. By the help of criteria processes, activities could be assessed which one actually corresponds to the real sustainability. It is evidence that shift paradigm is needed however by putting $\mathrm{SD}$ into practice new serious questions appear on the horizon.
\end{abstract}

Kulcsszavak: fenntartható fejlődés, fenntarthatóság, paradigmaváltás, fenntarthatósági kritériumok, gazdasági növekedés

Keywords: sustainable development, sustainability, paradigm shift, sustainability criteria, economic growth

\section{Bevezetés}

A fenntartható fejlődés, fenntarthatóság fogalma gyakorlatilag hétköznapi kifejezésekké váltak. A tartalma, és az, hogy miként kell értelmezni, hogyan kell ténylegesen megvalósítani a napi gyakorlatban, mit jelent ez a társadalom számára, viszont vitatott, többféleképpen értelmezett - sőt felvetődik, hogy egyáltalán létezike fenntartható fejlődés? Ez a tanulmány ennek tisztázásához kíván támpontot adni, felvillantva azokat a problémákat, amit a fenntarthatóság, fenntartható fejlődés megvalósítása jelent e dolgozatban bemutatott értelmezés alapján.

Vitára adhat okot maga az is, hogy igaz-e a fenntarthatóság, a fenntartható fejlődés egyenértéküsége? E munka elfogadja, hogy egyenértéküek. Ennek oka a tartalmi gyökerükben van. Ezáltal a „fenntarthatóság” szó tartalma eltér számos mai használatától.

\section{Az elméleti kutatás célja, módszertana}

A kutatás elméleti síkon kívánja tisztázni azt, hogy a fenntartható fejlödésnek, mint napjainkban leginkább elfogadott fejlődési iránynak mi alapján lehet megtalálni alapvető lényegét. Érdemes lefektetni azokat a mélyebb gyökereket, amelyek a fenntartható fejlődést célzó cselekvések, tevékenységek meghatározó alapja kell, 
hogy legyen. Ez ténylegesen szükségszerüség, s nem kívánalom. Indoka az, hogy a fenntarthatósági szempontú vizsgálatok eredményei tudnak olyan meghatározó cselekvési kereteket adni a társadalom szereplöinek, mellyel valóban a jövőbeli utódok érdekeit képviselik.

A kutatás ezért a szakirodalomra, neves szerzők munkájára építve tudja felvázolni javaslatait. Amiatt, hogy megszámlálhatatlan munka foglalkozik a fenntartható fejlődés, fenntarthatóság problémakörével, sajnálatosan csak összegző, szintetizáló vagy meghatározó új felvetések szerzői kerülnek említésre - elnézést kérve mindazoktól, akik szintén hozzájárultak e terület kimunkálásához.

\section{A fenntarthatóság (fenntartható fejlődés) történeti váza}

A fenntarthatóság történelmének rövid áttekintése segít felismerni a múlt tudását. Korunk problémája az, hogy oly mértékben megváltozott az együttélésünk a természettel, hogy az - sokak szerint - az emberiség létét fenyegeti. (Meg kell jegyezni, hogy - véleményünk szerint - ez kevéssé valószínủ mindaddig, amíg Földünkön bármely népcsoport fenn tud maradni élőhelyén, függetlenül attól, hogy mi történik a mai fejlettnek tekintett civilizációval. Viszont az általunk hátrahagyott hulladék, szennyezés, mérgező anyagok, stb. jelentős kockázatot jelenthet egy újra terjeszkedő, de ismerethiányos emberek számára!)

A fenntartható fejlődés gyökerei tartalmi szempontból az ősi társadalmak koráig nyúlnak vissza. A természeti környezetükkel harmóniában élő népek a saját környezetük olyan szintü felhasználására alakítottak ki szabályokat, melyek a megfelelő életfeltételek fennmaradását biztosították. Ha ezen túlléptek, akkor számolhattak a közösséget érő csapásokkal, akár annak elpusztulása következhetett be (Húsvét-sziget). Ezért a közösségek döntő többsége olyan szabályokat alakított ki, amelyek biztosították a fennmaradásukat, ökológiai környezetük folyamatos fennmaradását.

Ennek egyik példája Francia Polinéziából (Raiatea) a gondos erőforrás felhasználás példája, amit a közelmúltban is még meg lehetett figyelni. A szigetlakók a part mentén egy tengeri sávban tiltották a halászatot, hogy lehetősége legyen a halállománynak a megújulásra. Súlyos szankcióval sújtották a tabut megszegő lakosokat. A hagyományos nevelő célzatú szankciókat sikeresen modernizálták. Nem túl régen a tiltott zónában halászó fiatalokat büntetésként a tv nézés megvonásával sújtották. (Ma már valószínüleg az internet világából történő kizárást alkalmazzák.) Ez a fenntarthatóságot szolgáló gazdálkodás szabályozásának, fejlődésének klasszikus példája.

Európában a hasonló elvet követő váltógazdálkodás, ugaroltatás, a trópusokon, az esőerdők területén a falu közeli erdők változó szektorainak kivágása, mind a múltban megvalósított, ténylegesen a fenntartható fejlődésnek a fogalom ismerete nélküli megvalósításai. Az Európából kiindult civilizáció korábbi térhódítása így hordozott magában ilyen elemeket (Kincses et al., 2013). Vannak, akik az ipari forradalom kora előtti tartamos erdőgazdálkodást tekintik a fenntarthatóság első mérföldkövének. 
A II. világháború után jelent meg egy úttörő, de ma már alig ismert könyv, amelyik a háború utáni gyors fellendülés vegyiparának környezeti következményeit tárta fel. Így szerzője a fenntarthatóság korai harcosa a 20. század utolsó harmadának elején. Rachel Carson „Néma tavasz” címü munkája (1962; 1994) nemzetközi szinten döbbentette rá a világot a környezetszennyezés problémájára. A biológiai, fizikai kutatások egy része az 1970-es évek elején a környezeti problémák felé fordult.

Utóbbival egyidőben következett be a gazdasági növekedés és fogyasztás növekedési paradigmájának megkérdőjelezése. Megfogalmazódott a környezeti költségek, az externáliák gazdasági szerepe (Gyulai et al., 2003). A Római Klub jelentése, a „Növekedés határai” (Meadows et al., 1972) az egész világra kiterjedő hatást váltott ki drámai víziójával. A prosperáló gazdaságok vezető szereplői azonnal éles kritikával illették a tömören exponenciális folyamatokat extrapoláló kutatást. Ugyanis a Meadows-modell a népesség és a gazdaság exponenciális növekedésével számolt. Ez alapján a nem megújuló természeti erőforrások kereslete és a termelés okozta szennyezés mértéke is folyamatosan növekszik. Mivel az élelmiszer (víz) és a nem megújuló erőforrások készletei végesek, az exponenciális növekedés kimeríti a forrásokat és ez a véges földi rendszerben a társadalmak összeomláshoz vezet.

\section{A ENSZ tevékenysége, fenntartható fejlődés definíciója}

A világ egészére kiterjedő probléma súlyát jelzi az ENSZ 1972-ben, Stockholmban rendezett konferenciával fémjelezhetö környezetvédelmi tevékenysége. A megoldás keresése érdekében létrehozott Brundtland-bizottság (Környezet és Fejlödés Világbizottság) 1987-ben adta ki „Közös jövőnk” címü jelentését, mely a korábbiakhoz képest meghatározó előrelépést jelentett a növekedési paradigma és az erőforrás-felhasználás végességének ellentmondásában. Bár sokak szerint a jelentés fordulópont volt a környezeti problémák kezelésében, vannak, akik magának az abban megfogalmazott fenntartható fejlődés fogalmának a „létét” sem fogadják el.

Egyértelmü, hogy a fenntartható fejlődés fogalma az ENSZ Környezet és Fejlődés Világbizottság 1987. december 11-i jelentésében fogalmazódott meg áttörő jelentőséggel, igaz gyökerei - vitathatóan - 1972-ig nyúlnak vissza. A nemzetközi szinten elfogadott, eredeti dokumentumban foglalt megfogalmazás szerint:

„a fenntartható fejlödés olyan fejlödés, amely kielégíti a jelen szükségleteit, anélkül, hogy veszélyeztetné a jövő generációk esélyét arra, hogy ők is kielégithessék szükségleteiket"

eredeti angol szöveg: „...sustainable development, which implies meeting the needs of the present without compromising the ability of future generations to meet their own needs..." - (Brundtland, 1987).

A „Közös jövőnk” jelentés a fenntartható fejlődés fogalmán túl a környezeti kérdések kapcsán a globális szintủ felelősséget is hangsúlyozza. A gazdasági növekedés és a környezetvédelem egymást kiegészítő jellege olvasható ki a dokumentumból. Viszont nem jelenik meg a gazdasági növekedés és annak környezeti következményeivel szembeni elhatárolódás. A gazdasági növekedés és a 
jólét, illetve a fenntartható fejlödés kapcsolatára nem sikerült közös nevezőt találni (Ekins, 1993).

Az ENSZ tevékenységének sorsfordító lépése volt az 1992-ben a Rio de Janeiroban tartott ENSZ Világkonferencia. Az elsősorban klímaváltozásra és a biodiverzitás csökkenésére, mint alapvető problémákra fókuszáló Környezetről és a Fejlődésről nevü találkozó eredménye az Agenda 21 cselekvési terv lett, ami a fenntartható fejlődéssel kapcsolatos szakpolitikai lépések elveit foglalta magában, további lépések elöre vetítésével. A konferencia egyik fö üzenete a fejlett országok felelősségének kérdése volt. Ennek alapján a fejlettebb országoknak vezető szerepet kell játszaniuk a környezeti problémák megoldásában (Redclift, 1996).

A globális problémák megoldásának ma érvényes, 2015 szeptemberében New Yorkban egyhangúan elfogadott dokumentuma, az Agenda 2030. Hivatalos nevén: Transforming our World: The 2030 Agenda for Sustainable Development. Ennek középpontja a Fenntartható fejlődési célok (Washington State University Sustainable Development Sourcebook, 1998). A 17 célcsoport kiterjed a társadalom és a gazdaság egészére, emberséges, igazságos, a fenntarthatóságnak megfelelő világ létrehozását célozza.

\section{A fenntartható fejlődés fogalmának problémái két definíció alapján}

Az ENSZ által elfogadott meghatározás annak ellenére, hogy általánosan elfogadott, könnyen illethető kritikai észrevételekkel. De ugyanúgy rá lehet világítani más megfogalmazások hiányosságaira, problémáira is (Simonyi, 2002). Gyakorlatilag nem született a fenntartható fejlödésnek olyan definíciója, ami precízen le tudja írni azon lényegi elemeit, amely azért minden meghatározási kísérletből többé-kevésbé kiolvasható. Számtalan meghatározás született, melyek más megfogalmazással más hangsúlyokat hordoznak. (Széleskörü áttekintést nyújt a fenntartható fejlödés definíciójával foglalkozó munkákról az irodalomjegyzékben található két web-cím.) Itt két kiemelkedő definició, H. E. Daly és az ENSZ definíciójának vizsgálatára kerül sor.

\subsection{Daly fenntartható fejlödés meghatározása}

Az egyik legismertebb H. E. Daly, az ökológiai közgazdaságtan „atyja” által megfogalmazott definíció: „a fenntartható fejlődés a folytonos szociális jólét elérése, anélkül, hogy az ökológiai eltartó-képességet meghaladó módon növekednénk" (Gyulai, 2003). Daly szerint a viszonyítási alap az ökológiai eltartó-képesség. Ezt megtartva lehet csak hosszú távon növelni a szociális jólétet, azaz ez a természeti, ökológiai korlát. Tehát tisztában kell lennünk az ökológiai eltartó-képességgel, mind a Föld egészére, mind egyes területeire. Azonban egy terület eltartó-képessége nem konstans. A technológiai, gazdasági változások, ezek környezeti hatásai nem állandók (Gál-Szabó, 2017). Jellemzően napjainkban csökkentik az eltartóképességet. A biodiverzitás, az ökoszisztémák megújuló képességének csökkenése jól jelzi, hogy csökken az érintett területen az eltartható biológiai populáció nagysága. Az eltartó-képességet a megváltozó népesség mellett a humán cirkuláció is befolyásolja kis mértékben, jelentősebben a migráció. Amely folyamatok a 
turizmussal kiegészülve igazolhatóan növekvő jelentőségüek (Illés, 2013; Illés,

2007). Hasonló jelentőséggel bírnak az élelmiszertermelés és az élelmiszerfogyasztás globális és lokális tényezőinek módosulásai is (Kis-Pesti, 2015).

Az eltartó-képesség mellett tisztázni szükséges azt is, hogy mi az a szociális jólét? Az egyéni szociális jólét a boldogság index alapján értelmezhető, de ez változó például az egyén élete során. (Az tény, hogy más a szociális jólét egy tehetős vállalkozó, egy bhutáni lakos számára. A boldogság ellenben döntően nem vagyon függö. Például magasabb a boldogság index az említett Bhutánban.) Emellett a jólét erősen anyagi kötődésű fogalom. Az újabban használt jól-lét jobban jellemzi a boldogság, a tényleges jólét tartalmát, utal az anyagiakon kívüli, megelégedettséget okozó tényezőkre. És mit érthetünk a folytonos fenntartás alatt? Vélhető, hogy pontosabb kifejezés lenne a „biztosítása” az „elérése” helyett - „fenntartható fejlödés a folytonos szociális jó-lét biztosítása...". Az elérés szó ugyanis vagy el nem ért állapotra utal vagy a folytonosság biztosítása nincs megoldva. Végülis növekedést céloz a megfogalmazás, mint fentebb bemutattuk, változó eltartó-képességre. Mindezen észrevételek ellenére fontos, meghatározó elemekre világít rá Daly megfogalmazása.

\subsection{Az ENSZ fenntartható fejlődés fogalma}

Az ENSZ jelentés (Brundtland-jelentés) a jelen szükségleteinek kielégítését olyan módon javasolja, hogy a jövő generációk szükségletei kielégítésének lehetősége ne kerüljön veszélybe. Azaz a ma cselekvésének tekintettel kell(ene) lennie a jövő generációkra.

Elméleti problémákra világít rá két kérdés:

- Tudjuk-e minden tekintetben, mi lesz a jövő generációinak a szükséglete?

- A jövő generációi tekintetében milyen időhorizontot vegyünk figyelembe?

Ezt a két problémakört tekintjük át az alábbiakban.

\subsubsection{A jövő generációk szükségletei}

Az ENSZ (brundtland-i) fogalom alapján ma ismernünk, de legalább becsülnünk kell(ene) a jövő generációk szükségleteit, hogy azok kielégítését bizonyos értelemben garantálni tudjuk.

A jövő generációk alapigényei viszonylagos pontossággal körvonalazhatók. Vannak olyan alapvető - biológiai létből fakadó - szükségletek, melyek kétséget kizáróan fel fognak merülni: a napi faj- és létfenntartás igényei (táplálkozás), szállás (hajlék), mozgás igények és energiaigények. A várható népesség alapján ezek az értékek - az energiaigényt kivéve - jól becsülhetők. Viszont az alapigények feletti szükségletek bizonytalanok. Nemcsak mértékük (kvantitás), hanem formájuk (kvalitás) oldaláról sem. (Nem felejtendő el, hogy a szükségleteket, kielégítésüket összefüggésrendszerükben is kellene vizsgálni.) 


\subsubsection{Az idötényezö}

A fenntarthatóság a jövőnek szól. A jövő generáció érdekeinek figyelembe vétele meghatározó kérdése az idődimenzió. Milyen időtávban vegyük figyelembe a szükségleteiknek kielégítése esélyének, képességének veszélyeztetését? 30 évre, 50 évre vagy többre tekintsük-e előre? Leginkább a három generációra kitekintés fogadható el minimumnak, ami ma már közelíti a 100 évet. Azaz ha ezt elfogadjuk, akkor ma már nem 2100-ig, hanem legalább 2120-ig kell(ene) előre tekinteni fenntarthatósági vizsgálatok, ilyen szemléletü tevékenység, tervezés, fejlesztés során.

Az előre kitekintés két legkritikusabb célterülete a globális klímaváltozás és egyes hulladéktípusok. Milyen hosszú időre tekintsünk előre akkor, amikor a hulladékprobléma megoldottságáról beszélünk? A deponált - különösen a veszélyes - hulladékok kockázatot jelentenek, súlyosan veszélyeztetők, katasztrófák forrásai lehetnek a jövőben, így kockázati tényezői lehetnek az élelmiszerfogyasztásnak is. Az idődimenzió kifejezetten rendkívül hosszú lehet! Egyes műanyagfajták hulladékká válva nemcsak eltartó-képesség csökkentők, hanem már rövid időtávon is káros hatásúakká válhatnak/váltak országok lakóit ellátó egyes élelmiszeradó rendszerekre.

Fokozottan igaz ez a probléma a vegyipari hulladékokra, de különösen a nagy aktivitású nukleáris hulladékokra. A nagy aktivitású nukleáris hulladék kiemelkedő kockázata mellett a leghosszabb idő dimenziójú. E hulladéktípus aktivitás csökkenése (veszélyességének csökkenése) rendkívül lassú. Erősen alulbecsült módszerrel is messze évszázados nagyságrenden túli kockázati elem. (Példaként egy 1000 MW teljesítményü PWR reaktor évente kiégő üzemanyagának az aktivitása 100-200 év alatt csak két nagyságrenddel csökken $\left(10^{19}\right.$ nagyságrendröl $10^{17}$-re, Bqben) és nagyjából 500 évtől millió pihentetési év nagyságrendig $10^{16} \mathrm{~Bq}$-ről csak 2 nagyságrenddel mérséklődik) (Csom, 1988: 79).

Felmerül a hosszú időn keresztül kockázatot jelentő hulladékot „termelö” iparágak esetében, hogy tekinthetők-e megfelelönek a fenntartható fejlödés szempontjából? Nem jelentenek-e elfogadhatatlan kockázatot az unokáinknak, utódjaiknak?

Mindezek erősítik azt a kérdésfelvetést, hogy látjuk-e, hogy meddig kell elöre tekintetnünk? Milyen időtávra tekintsünk ki, különböző anyagok különböző eliminációs időtartama esetén? Bízhatunk-e a technika fejlődésében?

Etikai kérdés-e, a hatalom révén vagy megegyezéssel meg lehet-e az időtávban állapodni? Elfogadtatható-e, hogy 3 generáción túl (100 év) ki nem zárható kockázatként értelmezhető, veszélyt jelentő anyag (hulladék) előállítását, keletkezését el kell kerülni? Ami ilyen kockázatot létrehozó tevékenység esetén szigorú értelemben morálisan akkor lehetne elfogadható, ha ezen anyagok keletkezése kapcsán a létrehozó tevékenység előnyöket élvezőinek - átlagos életében a semlegesítés, ártalmatlanítás, eliminálás végrehajtható legyen és hajtsák is végre. Más megközelítés, ha azt mondjuk ki, hogy adott tevékenység akkor folytatható, ha az ez által keletkezett veszélyes (nukleáris) hulladék ártalmatlanítási, eliminálási ideje nem haladhatja meg azt az időtartamot, amíg a hasznot hozó 
tevékenység folyt. (E módon nem terhelve a messze távoli jövő nemzedékeit.) Következtethető, hogy a három generációs vagy 100 éves elvárás enyhébb megközelítést takar.

\section{A fenntartható fejlődés, a fenntarthatóság mai helyzete}

A kifejezések mai használatában, leginkább a „fenntarthatóság” hihetetlen széles témakörben jelent meg. Meglepö, hogy e korábban egyesek által tagadott, nem elfogadott kifejezések milyen szerepet kaptak. Az is meglepö, hogy a fenntarthatóság, fenntartható fejlődés milyen összefüggésekben, és milyen gyakorisággal merülnek fel napjainkban. Ténylegesen divatszóvá váltak. Gyakorlatilag az elmúlt század utolsó évtizedek divatszavának, a „környezetvédelem”-nek helyét ma már a leginkább a „fenntarthatóság”, „fenntartható" kifejezések vették át. Piaci értékük lett. Egy termék, szolgáltatás eladhatóságát segíti, ha elhiszi a fogyasztó, hogy más termékekhez, szolgáltatásokhoz képest ezek megvásárlásával a jövő generációinak érdekében, felelősen cselekszik. Eközben nem kevésszer ezek valójában csak marketing eszközök, amelyek olyan tevékenységeket takarnak, amelyek nem felelnek meg az eredeti megfogalmazásból levezethető lényegi tartalomnak. Az természetesen - elvi szinten - pozitívan értékelhető, ha egy tevékenység a korábbinál jobban megfelel a fenntarthatóság kritériumának, de ennél lehetnek sokkal kedvezőbb alternatívák is. Példaként valamilyen iparág kevesebb energiát használ fel, viszont egy rendkívül energiaigényes tevékenységről van szó, ami önmagában mással helyettesíthető lenne. Az sem felel meg a fenntarthatóságnak, ha fajlagosan javulás tapasztalható, viszont a volumen növekedése miatt ennek eredménye elenyészik. (Példaként egyes cégek miközben beszámolnak környezetvédelmi erőfeszítésekről a klímavédelem területén, aközben jelentősen nő az üvegházhatású gáz (ÜHG) kibocsátásuk alaptevékenységükből.)

Világosan megfogalmazható az alapvető ellentmondás: ha egy gazdaságban, társadalomban minden fenntartható, az ténylegesen fenntarthatatlan. Vagyis nem nőhet korlátlanul a népesség, nem nőhet korlátlanul az anyagi termelés, ezen alapuló gazdaság. A Föld korlátos rendszer, s korlátos rendszerben nincs korlátlan növekedés (Vida, 2018; Gyulai, 2013; Náray-Szabó, 2006). Még az alapvető, esszenciális szükségletek kielégítése is korlátos bármilyen földrajzi területi dimenzióban. A szükségletek kielégítésének azonos módja jelenti a biztos korlátosságot. Más, állandóan fejlődő, változó kielégítési mód felveti a változás és kvázi-korlátlanság lehetőségét. Gyakorlatilag ez az állandó változási szükség és egyben igény jelenti a fenntartható fejlődés egyik tartalmát.

Ha tovább visszük ezt a gondolatot, akkor arra a következtetésre juthatunk, hogy a fejlett világban mai módon folytatott gazdasági tevékenységünkkel szinte minden pillanatban ellene teszünk mind a brundtland-i, mind a Daly-féle meghatározásban foglaltatnak. Ugyanis a hagyományos vagy korlátos erőforrások megújuló képesség feletti - ráadásul növekvő - kiaknázása, elfogyasztása, szinte teljes bizonyossággal veszélyezteti a jövő generáció létfeltételeit. Sajnálatosan kiváló, jó példa a túlhalászat vagy a hagyományos energiahordozók kiaknázása. Ez utóbbi esetben 
bizonyosak lehetünk-e abban, hogy képes lesz-e a jövő társadalma kielégíteni a lassan csökkenő mennyiségü, és így fluktuálva dráguló hagyományos energiahordozóival a ma növekvőnek kezelt energiaigényét? És az is, hogy elég idő és forrás áll-e, fog-e rendelkezésre állni, hogy békés módon átálljon az emberiség az alternatív megoldásokra? Látjuk-e a folyamatot teljes komplexitásában?

\section{A fenntartható fejlődés, fenntarthatóság elvi kérdéseiről}

Az elözőekben felvetettek remélhetően sejtetik, hogy „bizalmatlanság” merülhet fel a fenntartható fejlődés fogalmával, a fenntarthatósággal szemben. Számos jelentős kutató, gondolkodó egyszerủen tagadja ezen fogalmak létezését, de legalábbis értelmezhetőségét. Valóban a jelenlegi gazdaság-, politikai rendszer, a demokratikus piacgazdaság fennmaradását szolgálja a fenntartható fejlődés?

Vitatható, ahogy már az is, hogy mi a fenntartható fejlődés? Elv, filozófia, gyakorlati cselekvés vezérelve, ideológia? A fenntarthatóság jellemzö, jelzö, mozgató elv, vagy, ahogy Gyulai Iván írja mód? Netán hit vagy megvalósítható realitás? Vagy széles értelmü kultúra, ahogy Gyulai (2012) vélekedik? Ez lehet az oka a meghatározások problémáinak is. Az elvi megalapozás során vetődnek fel ezek a kérdések. Úgy is értelmezhető a fenntarthatóság, hogy a fenntartható fejlödés megvalósításának elve, módja, ahogy ez a tanulmány is használja. Sajátos, hogy bár a megvalósítás alapjai ingatagok, legalábbis annak látszanak, aközben a konkrét megoldásban ténylegesen már vannak eredmények.

Különösen nehézzé teszi a megoldást az a sajátosság, hogy a definíció szerint a fenntartható fejlődés nem egy körülírt célállapot, hanem fogalmi szóhasználata alapján egy speciális jellemzővel bíró folyamat, melyhez kötődő eredményesség (esély/képesség veszélyeztetés elkerülése) aligha látható előre világosan. Ez alapján kérdőjelezik meg sokan a megvalósíthatóságát. Emiatt merül fel a „hit” kérdése. Eszerint a fenntarthatóságban, fenntartható fejlődésben való hit szinte egy vallás. (Végülis magatartást szabályoz.) Ez a hit önmagában mégis a kívánt cél felé lehet hatással. (Vélhetően alkalmazható erre is a pszichológiában ismert „önbeteljesítő jóslat" jelensége.)

Lányi András példaként úgy látja, hogy az ökológiai gondolkodás alapján a fenntarthatóságnak és a szükségleteknek egymáshoz közvetlenül nincs közük. Ráadásul mind a fejlődés, mind a szükségletek fogalmával is alapvető problémák vannak. Megállapítása az, hogy a fenntarthatóság „politikai filozófiai és végső soron etikai kérdés" (Lányi 2010).

A létezik-nem létezik, elfogadható-elfogadhatatlan kérdésében ellentétes állásfoglalások mellett is mindkét nézet képviselői egyben teljes mértékben egyetértenek: a földi mai „fejlett” civilizáció jelen folyamatai - e civilizáció fennmaradására nézve - fenntarthatatlanok. 


\section{A fenntartható fejlődésen alapuló fenntarthatóság szemlélet gyökerei}

Annak ellenére, hogy számtalan probléma, kritika, vitatott kérdés merült fel, mégis vannak olyan szemléleti alapok, amelyekre a konkrét megvalósítás, vizsgálat épül/épülhet.

A szemlélet egyes elemei:

- a jövő generációi szükségleteinek figyelembevétele;

- holisztikus szemlélet;

- rendszerszemlélet;

- interdiszciplináris szemlélet;

- korlátosság figyelembevétele (erőforrás takarékosság, takarékos életmód);

- természeti környezettel együttélés;

- szükséglet preferencia;

- körfolyamat szemlélet;

- ok-kezelés.

A meghatározó alap a hosszabb távú kitekintés, ami a jövő generáció tekintetbe vételét jelenti. A holisztikus szemlélet szerint az egész szemlélete, ilyen irányultságból, erre figyelemmel végezzük tevékenységünket, cselekszünk, a részek, részelemek célzottsággal ellentétben. A rendszerszemlélet azt jelenti, hogy nem pusztán, mint „fekete doboz”, hanem mint összefüggő müködő rendszer tekintünk példaként a természetre, tevékenységünkre. Szemléletünk emellett interdiszciplináris, azaz „szakbarbársággal” szemben a tudomány sokszínűségén alapul. Az erőforrás takarékosság minden erőforrásra érvényes a legszélesebb értelemben és spektrumban, minden termelési, szolgáltatási ágazatban. A fenntarthatóság csak akkor valósítható meg, ha a természet leigázása helyett a természettel való együttélés az alapelv. A szükséglet preferencia azt jelenti, hogy nem szabad engedni a fogyasztói társadalom csábításának, a birtoklás, mint hatalom vonzásának. A tényleges szükségleteinket elégítjük ki, nem az igényeinket. (Nem vesszük meg a sokadik terméket bármilyen, többnyire aligha könnyen igazolható okból. Megvalósítása azért problémákkal terhelt.) A gazdaságra, termelési folyamatokra szükséges, hogy a körfolyamatok kialakítása legyen jellemző. Ami a bioszféra müködéséhez hasonlítható. Az ok-kezelés azt takarja, hogy nem a probléma okozatának megoldására kell megoldásokat találni és erőfeszítéseket tenni ennek érdekében, hanem az elöidéző okokat kell megszüntetni, mérsékelni.

A fenntarthatósági vizsgálatoknak, a fenntarthatóságnak megfelelő gazdaság, társadalom életének ezeken kell alapulnia. Értelemszerüen a napi életre, az egyénre is vonatkoztathatók ezek az elemek

\section{A fenntartható fejlődés egyes gyakorlati kérdései, a fenntarthatóság kritériumai}

Eltekintve a további érvek, ellenérvek megvitatásától, tekintsük át, milyen további kérdéseket jelent az, ha elfogadjuk a fenntartható fejlödés, a fenntarthatóság gondolatának esszenciális alapját. Számos problémát kell végiggondolni, és meg kell próbálni választ adni rá, annak érdekében, hogy mitől lesz valami olyan, ami 
megfelel a fenntarthatóság elemeinek. Ezek tekinthetők a fenntarthatóság kritériumainak. Melyek a megvalósítás alapjai.

Az ENSZ definícióból következik, hogy a jövő generációira tekintettel kell megtervezni, müködtetni, fejleszteni a mai társadalmakat, azok gazdaságát. Gyakorlatilag az emberi tevékenység teljes spektrumában. Azonban az, hogy melyik cselekvés felel meg a fenntarthatóságnak, önmagában nem könnyen állapítható meg. Első annak megállapítása, hogy nem vélt szükségletről vagy netán igényről van-e szó? Valós szükséglet kielégítése elengedhetetlen. A kielégítési módok között leginkább csak, mint alternatívák között lehet megmondani, hogy melyik felel meg a fenntarthatóságnak és melyik nem. Példaként a közérthetővé tétel érdekében egy épület hőszigetelése megfelel a fenntarthatóságnak. A hőszigetelés anyaga már fenntarthatósági kérdés. Sokkal összetettebb a közlekedés fenntarthatóságáról beszélni, amikor azonos célt szolgáló megoldások, alternatívák között lehet választani. A fenntarthatóság korrekt megállapításához legtöbbször magának a terméknek a vizsgálata vezet. Eszköze lehet az életút-elemzés, ami azonban módszertanából fakadóan óvatosan kezelendő. (Termék alatt egyes szolgáltatások is értendők.)

Jogosan vetődik fel már önmagában az egyes szükségletek kielégítésének fenntarthatósága. Számtalan, valójában nem lényeges szükségletre teremt igényt korunk fogyasztói társadalma, melyek tényleges fontossága megkérdőjelezhető. (Például, hogy távoli kontinensek termékei egész évben megvásárolhatók az élelmiszerpiacon.) A szükségleteken túli kívánalom tekinthető igénynek.

\subsection{A fenntarthatóság kritériumairól}

A fenntarthatósági kritériumok alapja a jövő generációk szükségleteire kitekintés. Az ennek megfelelő felelös cselekvés, tevékenység. Legfontosabb jellemzői közé tartoznak:

- az anyag- és energia- (erőforrás) takarékosság és a természet, biodiverzitás megóvása;

- természetes anyagok használata;

- a szennyezés, környezetterhelés, hulladék kibocsátás minimalizálása, megszüntetése;

- a kényszerűen keletkező hulladékok, melléktermékek hasznosítása (a hulladék-piramis következetes alkalmazása).

Ágazatonként, termelési, fogyasztási lánconként végig lehet vezetni, hogy konkrétan ez mit takar. Akkor a legelönyösebb, ha a takarékosság költségmegtakarítást jelent (win-win, győztes-győztes megoldás). Kutatások egyes természeti erőforrások felhasználásra, illetve környezetterhelésre nyújtanak adatokat (ökológiai lábnyom, vízlábnyom, szén-dioxid lábnyom).

Példa lehet egy előzetes építőipari elemzés. Az építőipari láncban a nyersanyag takarékosságot az jelenti, ha hulladékot, építőipari hulladékot dolgoznak fel, a felhasznált nyersanyagok, alapanyagok mennyisége a lehető legkevesebb. Számít, hogy mennyi segédanyagot használnak fel (pl. víz). Természetes, újra termelődő anyag felhasználása mellett az is a fenntarthatóságot szolgálja, ha helyi anyag 
felhasználására kerül sor. Jó, ha a közelröl szállított anyagok csomagolása környezetkímélö, környezetbarát, lehető legkevesebb, legkisebb. Nem lényegtelen az sem, hogy mennyi és mennyire természetidegen anyagok felhasználására kerül sor. A felhasznált energia, a kibocsátott szennyező anyagok mennyisége, az üvegházhatású gázok kibocsátása is fenntarthatósági mérték. Az építés esetén felhasznált természeti terület, keletkezett hulladék ugyanúgy fenntarthatósági kérdés, mint az, hogy a beruházás esetén sikerült-e minimalizálni a területigényt. Épület esetén nem csekély jelentősége van annak, hogy milyen az épület tájolása, első lépésként a passzív napenergia hasznosítás mennyire valósul meg, ami a megfelelő tájolást jelenti - ha terv egyéb jellemzőitől most eltekintünk. Összességében az ökológiai lábnyom minimalizálásának meghatározó célnak kellene lennie.

Minden olyan tevékenység, ami fenntarthatósági, itt felsorolt kritériumoknak közvetlenül vagy közvetve ellentmond ,jogtalanul” használja a fenntartható, fenntarthatóságnak megfelelő, fenntartható fejlődést szolgáló bármelyik jelzőt. Így a fenntartható gazdasági növekedés sem felel meg a kritériumnak a mai gazdasági rendszerben, mert gyakorlatilag növekvő nyersanyag-, energiaigényre, állandó növekedésre épül.

\section{A fenntarthatóság megvalósításának sürgető igénye: a paradigmaváltás}

A mai gazdasági rendszerek paradigma váltásának időszerüsége számtalan esetben megfogalmazódott. A nemnövekedés mozgalmi eredetü, a Római Klub tevékenységéhez kötődik. Elődeinek az angol XIX. századi antiindusztriális mozgalmak képviselői tekinthetők (D'Alisa et al., 2015). Újdonság erejü az a munka, ami a paradigmaváltásnak nem a „szokásos” pusztán gazdasági, társadalmi, hanem erkölcsi alapjait kutatta.

A megvalósítás, a paradigmaváltás etikai alapjait, tényleges lehetőségét Baritz Sarolta Laura OP 2016-ban megjelent könyvében írta le, vallásetikai megközelítésből (Baritz, 2016). Bemutatja az erényetikai értékrend, az ezzel együtt járó erényetikai profitszemlélet lehetőségét és pozitív korrelációját. Az ennek megfelelő homo reciprocans, a kölcsönösség alapon élő, erényetikai ember képviseli az „objektív” jót, szemben a homo oeconomicussal, aki önérdeket követ. Reménye szerint az általa kifejtett erényetikai gazdaság igénye kívánatos és eszméje remélhetően egyre szélesebb körben ismertté és elfogadottá válik.

Még számos gondolat kifejtésre szorulna, mint például mit jelent az az alaptétel, hogy az anyag- és energiatakarékos megoldások felelnek meg a fenntarthatóságnak. Holisztikus szempontból közelítve ezt a kiindulást, magát a fenntartható fejlődés megvalósítását, számtalan olyan új kérdés, megoldandó probléma merül fel, amiket fenntarthatósági paradoxonoknak lehet nevezni. Ennek tárgyalására külön tanulmányban van lehetőség. 


\section{1. Összegzés}

A fenntarthatóság, fenntartható fejlődés napjainkra széles körben ismert kifejezésekké váltak.

Használatuk szinte mindennapos. Piaci értékűvé válásukat a globális problémákra adott nemzetközi válaszok, az ENSZ problémamegoldó erőfeszítései segítették. Amiatt terjedtek el, hogy a múlt század utolsó negyedétől a kutatók által jósolt folyamatok, változások lassan a teljes emberiség számára tapasztalhatóvá váltak.

A fenntarthatóság, a természettel való együttélés történelmi örökségünk. Ezt a képességet az ipari forradalom óta fokozatosan vesztette el a nyugati civilizáció. A felmerült problémák megoldása érdekében készült el az ENSZ munkája nyomán a fenntartható fejlődés megfogalmazása 1987-ben. Használata azonban annyira elterjedtté vált, hogy szükséges annak tisztázása, mi is a tényleges fenntarthatóság? Hogyan fogalmazható meg, mi az, ami megfelel a fenntarthatóságnak, mi az, ami viszont nem? Attól függetlenül, hogy már számtalan definíció született a fenntarthatóságról, más tartalom kiemelésével, ténylegesen gyökerük azonos. A jövő generációi iránti felelösséget hangsúlyozó ENSZ megfogalmazás a Brundtlandjelentésben sem tökéletes, de jó közelítésként világszerte elfogadottá vált.

A fenntarthatóság, a fenntartható fejlődés értelmezése e különbségek ellenére lehetővé teszi, hogy az ilyen szempontú gondolkodás fö elemeire építve lehet a fenntarthatósági kritériumok megállapítását megkísérelni. Jól látható, hogy a fenntarthatóság igényli a paradigmaváltást, ami etikai alapú átalakulást, elkötelezettség vállalást is szükségessé tesz. Az egyik meghatározó szemléleti elemböl, a holisztikus szemléletből kiindulva az is felmerül, hogy a fenntartható fejlődés megvalósítása, a fenntarthatóság új problémák, ellentmondások irányába mutat, fenntarthatósági paradoxonok fedezhetök fel, ami új, önálló kutatásokat igényel.

\section{Irodalomjegyzék}

Baritz S. L. OP (2016): Háromdimenziós gazdaság: Lehet gazdálkodni erényetikai paradigmában. Kairosz Kiadó, Budapest.

Brundtland, G. H. (Chw.) (1987): 42/187 Report of the World Commission on Environment and Development. United Nations New York. <htp://www.un.org/documents/ga/res/42/ares42187.htm> (2016.10.22.)

Carson, R. (1962): Silent Spring. Houghton Mifflin, Cambridge [Massachusetts].

Carson, R. (1994): A néma tavasz. Katalizátor Iroda, Budapest.

Csom Gy. (1988): Atomenergia-rendszerek nukleáris üzemanyagciklusának továbbfejlesztési lehetőségei. Akadémiai Kiadó, Budapest.

D'Alisa, G., Demaria, F., Kallis, G. (2015): Degrowth - A Vocabulary for a New Era. Routledge, New York \& London.

Ekins, P. (1993): Cities and sustainability. AFRC-SERC Clean Technology Unit, ESRC Research Programmes Division, Swindon.

Gál J., Szabó M. (2017): Effects of agricultural machines on the environment. Quaestus Multidisciplinary Research Journal, 4: 221-227.

Gyulai I. (2012): A fenntartható fejlödés. Ökológiai Intézet a Fenntartható Fejlődésért Alapítvány, Miskolc. <http://www.mtvsz.hu/dynamic/fenntart/a_fenntarthato_fejlodes.pdf> (2020-03-02.) 
Gyulai I. (2013): Fenntartható fejlödés és fenntartható növekedés. Statisztikai Szemle, 91 (8-9): 797822.

Gyulai I. et al. (2003): Fenntartható fejlődés. in Magyar Virtuális Enciklopédia, MTA, Budapest.<http://www.enc.hu/lenciklopedia/fogalmi/korny/fenntartfej.htm> (2012.02.05.)

https://unsdg.un.org/2030-agenda (2020 03. 08.)

Illés S. (2007): Polgármesteri szemmel a turizmusról és a migrációról. Comitatus, 17 (10): 50-66.

Illés S. (2013): Időskori nemzetközi migráció - magyar eset. Tullius Kiadó, Budapest.

Kincses Á., Nagy Z. Tóth G. (2013): The spatial structures of Europe. Acta Geographica Slovenica, 53 (2) $43-70$.

Kis K., Pesti, K. (2015): Szegedi élelmiszeripari hungarikumok helyzete, lehetőségei a globalizáció és a lokalizáció kölcsönhatásában: eredet, hagyomány és minőség Szögediesen. Jelenkori társadalmi és gazdasági folyamatok, 10 (2): 9-34.

Lányi A. (2010): Miért fenntarthatatlan, ami fenntartható? - A környezetbarát gazdálkodás és a közösségi vállalkozás esélyei egy aprófalvas régióban. Tanulmány. Budapest. <http://beszamolo2010.jno.hu/cd/fuggelekek/2_kutatasok_eredmenyei/lanyi_orseg.pdf> (2019.12.15.)

Meadows, D. H. et al. (1972): The Limits to Growth. Universe Books, New York.

Náray-Szabó Gábor (2006): Fenntartható a fejlődés? Akadémiai Kiadó Zrt., Budapest.

Redclift, M. (1996): Wasted. Earthscan, London.

Simonyi, P. (2002): A fenntartható fenntartható fejlödés (?) és az oktatás. $<$ https://mtvsz.hu/dynamic/ff_kritika_simonyi_peter.pdf> (2020.03.03.)

Vida Gábor (2018): A fenntartható fejlódés helyzete. BME 2018. szeptember 5. www.epszerk.bme.hu $<$ https://www.google.com/url?sa=t\&rct=j\&q=\&esrc=s\&source=web\&cd=18\&ved=2ahUKEwj An9jfpO_1AhWEAhAIHdUBBIcQFjARegQIBBAC\&url=http\%3A\%2F\%2Fwww.epszerk.bm e.hu\%2Fdocs.php\%3Fn\%3D64643\&usg=AOvVaw2rf2MSSq_EIVZz8J37R4Yg> (2020.03.02.)

Washington State University Sustainable Development Sourcebook (1998) <https://public.wsu.edu/ $\sim$ susdev/> (2020.03.03.) 